Jurnal Kimia Sains dan Aplikasi 24 (1) (2021):15-21
ISSN: 1410-8917
Jurnal Kimia
Aplikasi

\title{
Isolation of a High Antioxidant Non-Toxic Polar Fraction from Garcinia mangostana Fruit Pericarp by Reverse Phase Column Chromatography
}

\author{
Wahyuningsih ${ }^{\mathrm{a}, \mathrm{b}}$, Miranti $^{\mathrm{a}}$, Hilwan Yuda Teruna ${ }^{\mathrm{a}}$,Titania Tjandrawati Nugroho ${ }^{\mathrm{a},{ }^{*}}$ \\ ${ }^{a}$ Department of Chemistry, Faculty of Mathematics and Natural Sciences, Universitas Riau, Pekanbaru, Indonesia \\ bUPT PSMB, Dinas Perindagkop UKM, Riau Province, Pekanbaru, Indonesia \\ *Corresponding author: titania.nugroho@lecturer.unri.ac.id
}

https://doi.org/10.14710/jksa.24.1.15-21

\begin{tabular}{l} 
Article Info \\
\hline Article history: \\
Received: $6^{\text {th }}$ November 2020 \\
Revised: $9^{\text {th }}$ February 2021 \\
Accepted: $24^{\text {th }}$ February 2021 \\
Online: $28^{\text {th }}$ February 2021
\end{tabular}

Keywords:

Garcinia mangostana; mangosteen; 2-2-diphenyl-1picrylhydrazyl antioxidant activity; Brine Shrimp Lethality Assay, total phenolic content

\begin{abstract}
The crude polar extract of mangosteen fruit pericarp not only has a moderate antioxidant activity of $(55 \pm 4 \mu \mathrm{g} / \mathrm{mL})$ but also has high cytotoxicity $(16 \pm 0.5$ $\mu \mathrm{g} / \mathrm{mL}$ ). The high cytotoxicity presumably is caused by the presence of complex cytotoxic compounds from the mangosteen pericarp. To obtain a non-toxic extract preparation with high antioxidant activity, polar crude 50\% ethanol extracts of mangosteen pericarp were partially purified using reverse-phase column chromatography with Silica C18 as the stationary phase and acetonitrilewater gradient elution. Six of the ten fractions collected had high antioxidant activities, with $\mathrm{IC}_{50}$ 2,2-diphenyl-1-picrylhydrazyl (DPPH) radical scavenging antioxidant levels $<50 \mu \mathrm{g} / \mathrm{mL}$. Three fractions (fractions 3,5 , and 7 ) with the highest antioxidant activities of $(16.4 \pm 0.6 \mu \mathrm{g} / \mathrm{mL}),(17.8 \pm 2 \mu \mathrm{g} / \mathrm{mL})$ and $(17.4 \pm$ $1.8 \mu \mathrm{g} / \mathrm{mL}$ ) respectively, were chosen for further cytotoxicity, phenolic content and High-Performance Liquid Chromatography (HPLC) analysis. The cytotoxic tests were conducted with the Brine Shrimp Lethality Assay. Fraction 3 had low cytotoxicity $\left(\mathrm{LC}_{50} 485 \pm 96 \mu \mathrm{g} / \mathrm{mL}\right)$ and fraction 5 was non-toxic $\left(\mathrm{LC}_{50} \geq 1000\right.$ $\mu \mathrm{g} / \mathrm{mL}$ ), while fraction 7 still had high cytotoxicity $\left(\mathrm{LC}_{50} 2.8 \pm 0.8 \mu \mathrm{g} / \mathrm{mL}\right.$ ). The chromatogram profiles of HPLC showed that fractions 3 and 5 contained more polar compounds than the compounds present in fraction 7. It can be concluded that the reverse phase method succeeded in the isolation of a non-toxic polar fraction, that is, fraction 5 , with a significantly higher $(p<0.05)$ antioxidant activity than in the original crude polar extracts. This fraction had a high total phenolic content of $43.3 \pm 0.3 \mathrm{~g}$ GAE per $100 \mathrm{~g}$ extract.
\end{abstract}

\section{Introduction}

Mangosteen (Garcia mangostana Linn.) is a member of the Clusiaceae family and cultivates in South-East Asia's tropical climate. The fruit pericarp of mangosteen is used as herbal medicine in South-East Asia to treat dermatitis, wound inflammation, diarrhea, cholera, and dysentery [1]. Mangosteen pericarp contains a wide variety of compounds with biological activities. The most studied to date have been the non-polar compounds from the xanthone family, such as the $\alpha$-mangostin [2], $\beta-$, and $\gamma$-mangostin [3]. These xanthone compounds have been shown to exhibit anti-cancer [4], anti-diabetic [5], and anti-rheumatoid arthritis properties [1].
Apart from the xanthones, mangosteen pericarp also contains other phenolic and polyphenolic compounds such as anthocyanin [6], vanillic acid, quercetin, rutin, protocatechuic acid, catechins, and epicatechins [7]. Other biological activities attributed to mangosteen pericarp phenolic extracts have been antibacterial agents [8] and antioxidants [7].

Recently, polar extracts from mangosteen fruit pericarp have attracted attention due to the growing data on polar phenolics and polyphenolics' medicinal properties. Like the non-polar $\alpha$-mangostin, polar extracts of mangosteen fruit pericarp also have antioxidative properties [9]. Pothitirat et al. [10] showed that 
phenolic compounds and tannin contributed major antioxidant activities in mangosteen fruit pericarp polar fractions. Furthermore, the free radical scavenging activity of polar phenolic compounds from mangosteen fruit pericarp was significantly higher than xanthones' activity [9]. Polar phenolic compounds extracted from mangosteen fruit pericarp have also been shown to alleviate exaggerated vasoconstriction in metabolic syndrome-induced rats [11]. A diet of polar phenolics extracted from mangosteen fruit pericarp given to rats in conjunction with a high-fat diet also could prevent thickening of the rats' blood vessel walls, thus preventing atherosclerosis [12].

Polar phenolic compounds from mangosteen fruit pericarp are easily extracted by $50 \%$ to $70 \%$ ethanol. Suttirak and Manurakchinakorn [13] suggested that 50\% ethanol extracts are the preferred solvent for extracting mangosteen fruit pericarp antioxidants. However, our preliminary study of a $50 \%$ ethanol mangosteen fruit pericarp extract showed that it was toxic when applied to keratinocyte cells in vivo, with an $\mathrm{IC}_{50}$ of $5.3 \mu \mathrm{g} / \mathrm{mL}$ [14]. Fractionation of this crude extract by gel filtration chromatography and its subsequent analysis revealed that the crude extract's cytotoxicity activity was not caused by low molecular weight salts but rather by higher molecular weight compounds originating from the mangosteen fruit pericarp. Furthermore, no fraction from the gel filtration method had the three combined desired target properties of having high antioxidant activity, high phenolic content, and being a non-toxic fraction [15].

Several other methods can be employed to fractionate polar phenolic compounds from a crude extract. One method is reverse-phase liquid chromatography, commonly used to separate and analyze polyphenols and other phenolic compounds in plant extracts [16]. This paper presents our results of fractionation of a crude polar extract from Garcinia mangostana fruit pericarp by reverse-phase liquid column chromatography, intending to obtain a non-toxic fraction having high phenolic content and high antioxidant activity.

\section{Methodology}

This research was initiated by preparing crude ethanol $50 \%$ ( $\mathrm{pH} 5.5$ ) extracts of mangosteen pericarp. The $50 \%$ ethanol mangosteen dry crude extracts were then fractionated by reverse-phase liquid column chromatography (RP-LC), using Silica $\mathrm{C}_{18}$ as the stationary phase and a water-acetonitrile gradient as the mobile phase. Each fraction obtained from the RP-LC process was analyzed for its antioxidant activity using the free-radical scavenging method. Its total phenolic content was using the Folin-Ciocalteau, its cytotoxicity was using the Brine Shrimp Lethality Assay (BSLA) method. Fractions with the highest antioxidant activities were also analyzed using analytical High-Performance Liquid Chromatography (HPLC).

\subsection{Equipment and Materials}

The equipment used in this study was a spectrophotometer microplate reader (Berthold Technology TriStar LB 941, Germany); Thermo Scientific Genesys 10S UV-Vis spectrophotometer; HighPerformance Liquid Chromatography (HPLC) Agilent 1200 Series. Other laboratory standard tools used were according to the experimental procedures.

Materials used in this study was mangosteen ripe fruits purchased from local markets in Pekanbaru, Riau Province, Indonesia; 2-2-diphenyl-1-picrylhydrazyl (DPPH) (Sigma-Aldrich Cat. No. D9132-IG), Silica $\mathrm{C}_{18}$ (Chromatorex Cat. No. CRX-002-000-E); gallic acid (Sigma-Aldrich Cat. No.G7384-100G), Folin-Ciocalteau reagent (Merck Cat.No.1.0046.0100); and Great Salt Lake Artemia Cysts was from Sanders Brine Shrimp Co.(Utah, USA). All other reagents and organic solvents were of analytical grade, as described in the experimental procedures.

\subsection{Preparation of Polar Mangosteen Fruit Pericarp Crude Extracts}

Preparation of $50 \%$ ethanol ( $\mathrm{pH} 5.5$ ) crude extracts of mangosteen pericarp followed the procedure described by Miranti [17]. Briefly, 2.5 grams of powdered dry mangosteen pericarp was macerated in $25 \mathrm{~mL} 50 \%$ ethanol in a $0.05 \mathrm{M} \mathrm{Na-acetic} \mathrm{buffer} \mathrm{(pH} \mathrm{5.5)} \mathrm{for} \mathrm{eight}$ days with shaking at $100 \mathrm{rpm}$ in a $40^{\circ} \mathrm{C}$ incubator. The $50 \%$ ethanol extracts were then separated from the powdered residue by filtration, and the extracts were concentrated by vacuum rotary evaporation at $50^{\circ} \mathrm{C}$. The resulting concentrated extracts were further dried in a $70^{\circ} \mathrm{C}$ water bath for 2 hours, followed by air-drying at $50^{\circ} \mathrm{C}$ until constant weight.

\subsection{Reverse Phase Liquid Chromatography (RP-LC) Fractionation}

$50 \mathrm{mg}$ of dried crude polar fruit pericarp extracts were applied to a chromatography column $(1.5 \mathrm{~cm}$ diameter x $30 \mathrm{~cm}$ height), filled with Silica C18 as the stationary phase. The packed column was conditioned by washing twice with methanol and letting stand overnight before use. The column was eluted with a gradient wateracetonitrile solvent, starting with an initial ratio of $85 \%$ water: $15 \%$ acetonitrile and ending with a ratio of $5 \%$ water:95\% acetonitrile. The mobile phase gradient composition was changed every $25 \mathrm{~mL}$ by $5 \%$ for each solvent. Fractions of $25 \mathrm{~mL}$ each were collected. The fractions were evaporated under vacuum at $50{ }^{\circ} \mathrm{C}$ until concentrated and further air-dried at $50^{\circ} \mathrm{C}$ in an oven to constant weight.

\subsection{Antioxidant Activity Analysis by the Free Radical Scavenging Assay}

Each fraction's antioxidant activities were determined based on the 2,2 diphenyl-1-picrylhydrazyl (DPPH) radical scavenging activity, using 96 well microplate format according to the method as described by Zhang et al. [18]. Briefly, $10 \mu \mathrm{L}$ of DPPH solution $(80 \mu \mathrm{g} /$ $\mathrm{mL}$ in methanol) was added to microplate wells containing $90 \mu \mathrm{L}$ dried extract dissolved in methanol with 
various concentrations $(1000 ; 500 ; 250 ; 125 ; 62.5 ; 31.25$ $\mu \mathrm{g} / \mathrm{mL}) .10 \mu \mathrm{L}$ of DPPH solution $(80 \mu \mathrm{g} / \mathrm{mL}$ ) added to 90 $\mu \mathrm{L}$ methanol was used as a blank. Ascorbic acid was used as the positive control. The mixtures were incubated for 30 minutes at room temperature in the dark. Absorbance was measured at a wavelength of $520 \mathrm{~nm}$ using a Berthold Technology Tristar LB 941 microplate reader. Measurements of antioxidant activities were repeated in triplicate experiments. Inhibition concentration $50 \%$ (IC50) was determined by regression analysis of the data. The following equation calculated the percentages of DPPH inhibition.

$\%$ DPPH inhibition $=\frac{\text { Absorbance }_{\text {control }}-\text { Absorbance }_{\text {reaction mixture }}}{\text { Absorbance }_{\text {control }}} \times 100 \%$

\subsection{Total Phenolic Content Analysis}

Total phenolic content (TPC) of dried extracts and fractions were determined using an optimized FolinCiocalteu method $[19,20]$. In this method $0.1 \mathrm{~mL}$ of sample $(1 \mathrm{mg} / \mathrm{mL})$ was mixed with $0.5 \mathrm{~mL} 0.25 \mathrm{~N}$ FolinCiocalteu reagent and $0.9 \mathrm{~mL}$ deionized water. The mixture was incubated at room temperature in the dark for 5 minutes before adding $2.5 \mathrm{~mL}$ of $7.5 \% \mathrm{Na}_{2} \mathrm{CO}_{3}$. The mixture was further incubated in the dark, at room temperature, for another 20 minutes. The absorbance of the mixture was measured at $765 \mathrm{~nm}$ with a Thermo Scientific Genesys 10S UV-Vis spectrophotometer. A standard curve was generated by using various concentrations (50 to $400 \mathrm{ppm}$ ) of gallic acid. Total phenolic content was expressed as gallic acid equivalent (GAE) per $100 \mathrm{~g}$ of sample.

\subsection{Cytotoxicity Analysis}

Cytotoxicities of selected fractions were determined by The Brine Shrimp Lethality Assay (BSLA) [21]. Dried brine shrimp's eggs were hatched in a hatching chamber adequately aerated, having a dark and bright zone, and filled with seawater. The dark zone was filled with brine shrimp eggs to be hatched, while in the bright zone, a lamp was placed as a lighting source for incubation and nauplii separation. The chamber was incubated at room temperature $\left( \pm 30^{\circ} \mathrm{C}\right)$ for 48 hours. Active nauplii that hatched from its shell moved to the chamber's bright side after 48 hours of incubation. Active nauplii were picked using a pipette and added to fresh, clear seawater, ready for the BSLA. Dried fractionated mangosteen extract to be tested was dissolved in methanol with the concentration of 10,100 , and $1000 \mu \mathrm{g} / \mathrm{mL}$. $500 \mu \mathrm{L}$ of each concentration of the extract was added to test vials, and the methanol was allowed to evaporate at room temperature to dryness. Dried extract in each vial was then re-dissolved by adding $50 \mu \mathrm{L}$ LDMSO and $4.95 \mathrm{~mL}$ seawater. Ten nauplii were added to each vial. The vials were incubated at room temperature $\left( \pm 30^{\circ} \mathrm{C}\right)$ for 24 hours. After 24 hours, the number of dead and live nauplii were enumerated using a magnifying glass and a black background. The percentage of dead nauplii was corrected to the percentage of dead nauplii in simultaneously control experiments. The control experiments consisted of vials to which ten nauplii from the same hatched batch as test experiments were added to $50 \mu \mathrm{L}$ of DMSO and $4.95 \mathrm{~mL}$ of seawater and incubated at room temperature. All experiments were repeated three times. The mortality percentage was calculated using the following equation:

$\%$ Mortality $=\frac{\text { The numbers of dead test larvae }- \text { the numbers of dead control larvae }}{\text { The numbers of control larvae }} \times 100 \%$

Mortality percentages were plotted against the logarithmic value of the concentration of extracts. The value of $\mathrm{LC}_{50}$ was estimated using Finney's probit regression analysis statistical method [22].

\subsection{High-Performance Liquid Chromatography Analysis}

High-Performance Liquid Chromatography (HPLC) analysis was carried out using a Zorbax Eclipse C-18 column ( $4.6 \times 100 \mathrm{~mm}, 5 \mu \mathrm{m})$ attached to an Agilent HPLC 1200 Series (Agilent, Santa Clara, California, USA), with a Diode Array Detector-UV monitored at $240 \mathrm{~nm}$. The mobile phase was a gradient of water-acetonitrile ( $4: 1$, $\mathrm{v} / \mathrm{v}$ ), eluted for 20 minutes with a $1 \mathrm{~mL} /$ minute flow velocity. The mobile phase was a gradient of water and acetonitrile with the following gradient elution $0-20$ minutes $10 \%$ to $80 \%$ of acetonitrile in water and 2 minutes for equilibrium before the next injection. The flow rate of the mobile phase was adjusted to 1 $\mathrm{mL} / \mathrm{minute}$.

\subsection{Data Analysis}

The test results for antioxidant activities, total phenolic content, toxicity, and HPLC analysis are presented in tables and figures. The antioxidant activities, total phenolic content, and BSLA data were analyzed statistically, expressing averages as mean \pm SD. Data were analyzed by the one-way analysis of variance (ANOVA) followed by Duncan's New Multiple Range (DNMR) Test [23, 24].

\section{Results and Discussion}

The $50 \%$ ethanol crude extract of mangosteen fruit pericarp before fractionation had a DPPH free radical scavenging activity $(55.4 \pm 4.1 \mu \mathrm{g} / \mathrm{mL})$ and phenolic content of $37.3 \pm 1.3 \mathrm{~g}$ GAE per $100 \mathrm{~g}$ extract (Table 1 ). This crude extract was prepared in $50 \%$ ethanol and $\mathrm{pH} 5.5 \mathrm{Na}-$ acetate buffer to obtain high extract's high phenolic content. This was due to our preliminary study showing that extraction of polar phenolics from mangosteen fruit pericarp in $50 \%$ ethanol in a $\mathrm{pH} 7.0$ buffer resulted in a significantly lower phenolic content $(p<0.05)$ of $6.8 \pm 0.5$ g GAE per $100 \mathrm{~g}$ extract [25]. The $50 \%$ ethanol crude extract ( $\mathrm{pH}$ 5.5) of mangosteen fruit pericarp was fractionated using a Silica C18 column by RP-LC as described in the Methodology section. The ten dried fractions collected from this method were further analyzed for antioxidant activity, total phenolic content, cytotoxicity, and analytical HPLC profiles.

\subsection{Antioxidant Activity and Total Phenolic Content of RP-LC Fractions}

Antioxidant activity was measured as the ability of the sample solution to scavenge free radicals of DPPH. The antioxidant activity and total phenolic content of each fraction after RP-LC and the crude extract before RP-LC are shown in table 1. According to Phongpaichit et al. [26] the strength of antioxidant compound according 
to its DPPH radical scavenging activity can be categorized as very high $(<10 \mu \mathrm{g} / \mathrm{mL})$, high $(10-50 \mu \mathrm{g} / \mathrm{mL})$, moderate $(>50-100 \mu \mathrm{g} / \mathrm{mL})$, low $(100-250 \mu \mathrm{g} / \mathrm{mL})$, and has no significant amount of antioxidant activities (>250 $\mu \mathrm{g} / \mathrm{mL}$ ). According to these criteria, six fractions can be categorized as having high antioxidant activities from the ten collected fractions. This is a significant increase $(\mathrm{p}<0.05)$ compared to the original crude extract's antioxidant activity, which is categorized in the moderate antioxidant level.

The highest increase in antioxidant activity is seen in fractions 3, 5, and 7, having antioxidant activity levels ranging from 16 to $18 \mu \mathrm{g} / \mathrm{mL}$. This increase in antioxidant activity is due to the significantly higher $(p<0.05)$ Total Phenolic Content (TPC) observed in fractions 3 and 5 , compared to that in the original crude extract. However, not all increases in higher antioxidant activity in the collected fractions are due to increased TPC, as demonstrated in fractions 2 and 4. Fraction 7, which has a high antioxidant activity, also had a significantly lower $(p<0.05)$ TPC than the crude extract. Although having lower TPC content than the original crude extract, fractions 2, 4, and 7 still contain TPC levels between 18 to $32 \mathrm{~g}$ GAE per $100 \mathrm{~g}$ samples. Therefore, they can still be considered to contain phenolic compounds with antioxidant activity. Nevertheless, the presence of a nonphenolic substance in these fractions cannot be ruled out yet to increase the antioxidant activity compared to the crude extract since the analytical HPLC profile of fraction 7 (figure 1, section 3.3.) showed that this fraction still contained several compounds. A candidate non-phenolic polar antioxidant compound present in G. mangostana pericarp is vitamin C (ascorbic acid). Although the presence of ascorbic acid in mangosteen fruit pericarp has not been published, the fruit itself contains a high content of ascorbic acid [27].

Table 1. Antioxidant DPPH scavenging activity and TPC of dried extracts before and after RP-LC fractionation

\begin{tabular}{ccc}
\hline Sample & $\begin{array}{c}\mathrm{IC}_{50} \text { DPPH } \\
\text { scavenging } \\
\text { activity }(\mu \mathrm{g} / \mathrm{mL})\end{array}$ & $\begin{array}{c}\text { TPC }(\mathrm{g} \mathrm{GAE} \\
\text { per 100 g } \\
\text { sample) } *)\end{array}$ \\
\hline Crude original extract & $55.4 \pm 4.1^{\mathrm{e}}$ & $37.3 \pm 1.3^{\mathrm{c}}$ \\
Fraction 1 & $662.0 \pm 22^{\mathrm{h}}$ & $4.3 \pm 0.2^{\mathrm{h}}$ \\
Fraction 2 & $33.0 \pm 1.5^{\mathrm{d}}$ & $18.3 \pm 0.2^{\mathrm{e}}$ \\
Fraction 3 & $16.4 \pm 0.6^{\mathrm{b}}$ & $45.3 \pm 0.2^{\mathrm{a}}$ \\
Fraction 4 & $34.1 \pm 1.3^{\mathrm{d}}$ & $18.9 \pm 0.3^{\mathrm{e}}$ \\
Fraction 5 & $17.8 \pm 2.0^{\mathrm{b}}$ & $42.3 \pm 0.3^{\mathrm{b}}$ \\
Fraction 6 & $27.2 \pm 0.8^{\mathrm{c}}$ & $35.0 \pm 1.0^{\mathrm{c}}$ \\
Fraction 7 & $17.4 \pm 1.8^{\mathrm{b}}$ & $31.9 \pm 0.8^{\mathrm{d}}$ \\
Fraction 8 & $147.1 \pm 1.8^{\mathrm{g}}$ & $32.9 \pm 0.2^{\mathrm{d}}$ \\
Fraction 9 & $115.0 \pm 2.7^{\mathrm{f}}$ & $15.1 \pm 0.2^{\mathrm{f}}$ \\
Fraction 10 & $823.3 \pm 37^{\mathrm{g}}$ & $11.6 \pm 1.2^{\mathrm{g}}$ \\
Positive control for DPPH & $7.3 \pm 0.0^{\mathrm{a}}$ & \\
\hline scavenging (ascorbic acid) & 7.3 & \\
\hline
\end{tabular}

*) Values are means of three separate measurements. Different superscript alphabet in a column denotes significantly different means at the $5 \%$ confidence levels $(p<0.05)$ by the DNMR test.

\subsection{Cytotoxicity of fractions}

The three fractions with the highest antioxidant activities were chosen for further cytotoxicity analysis by the BSLA method. Table 2 shows the BSLA results concerning the antioxidant activities and TPC of the selected fractions and the original crude polar mangosteen fruit pericarp extract. According to Clarkson's Toxicity Criterion based on BSLA LC $\mathrm{C}_{50}$ values, herbal extracts having $\mathrm{LC}_{50}$ in the range of $0-100 \mu \mathrm{g} / \mathrm{mL}$ are highly toxic, $\mathrm{LC}_{50} 100-500 \mu \mathrm{g} / \mathrm{mL}$ are moderately toxic, $\mathrm{LC}_{50} 500-1000 \mu \mathrm{g} / \mathrm{mL}$ are in the low toxic levels, and $\mathrm{LC}_{50}>1000 \mu \mathrm{g} / \mathrm{mL}$ can be considered non-toxic [21]. The original crude polar extracts before fractionation had a moderate antioxidant activity of $55.4 \pm 4.1 \mu \mathrm{g} / \mathrm{mL}$ but also was highly toxic with a BSLA LC $_{50}$ of $15.6 \pm 0.5 \mathrm{\mu g} / \mathrm{mL}$. After RP-LC, fraction 3 still had low levels of toxicity, while fraction 5 was non-toxic. Fraction 5 is an ideal candidate for consumption. It is used as an herbal medicine for maintaining health in prolonging consumption since it is non-toxic, has high antioxidant activity, and a high TPC. Fraction 7, although it had significantly $(\mathrm{p}<0.05)$ higher antioxidant activity than the crude extract, was still as toxic as the crude extract.

Table 2. Summary of antioxidant activities, TPC, and cytotoxicity from selected fractions

\begin{tabular}{cccc}
\hline Sample & $\begin{array}{c}\mathrm{IC}_{50} \text { DPPH } \\
\text { scavenging } \\
\text { activity } \\
(\mu \mathrm{g} / \mathrm{mL}) *)\end{array}$ & $\begin{array}{c}\text { TPC }(\mathrm{g} \mathrm{GAE} \\
\text { per 100 } \mathrm{g} \\
\left.\text { sample })^{*}\right)\end{array}$ & $\begin{array}{c}\mathrm{BSLA} \mathrm{LC}_{50} \\
(\mu \mathrm{g} / \mathrm{mL}) *)\end{array}$ \\
\hline $\begin{array}{c}\text { Crude original } \\
\text { extract }\end{array}$ & $55.4 \pm 4.1 \mathrm{~b}$ & $37.3 \pm 0.7 \mathrm{c}$ & $15.6 \pm 0.5$ \\
Fraction 3 & $16.3 \pm 0.6 \mathrm{a}$ & $45.3 \pm 0.2 \mathrm{a}$ & $485.2 \pm 96.2$ \\
Fraction 5 & $17.8 \pm 2.0 \mathrm{a}$ & $42.3 \pm 0.3 \mathrm{~b}$ & $1186.9 \pm 295.9$ \\
Fraction 7 & $17.4 \pm 1.8 \mathrm{a}$ & $31.9 \pm 0.8 \mathrm{~d}$ & $2.8 \pm 0.8$ \\
\hline
\end{tabular}

*) Values are means of three separate measurements. Different superscript alphabet in a column denotes significantly different means at the $5 \%$ confidence levels $(p<0.05)$ by the DNMR test.

\subsection{Analytical HPLC analysis of selected fractions}

HPLC analysis chromatogram profiles of fractions 3, 5 , and 7 showed different constituent profiles present in each fraction, with fewer polar components appearing progressively from fractions 3 to 7 (Figure 1). Most of the crude extracts' cytotoxicity appears to have eluted at retention time peaks higher than 1.2 minutes. These are the same peaks found in fraction 7 but not present in fraction 3 or 5 . Fraction 5 still contained a compound present in fraction 3, eluting at the retention time of 0.5 minutes. The compound represented by 0.5 minutes retention time had lower concentration levels in fraction 5 than in fraction 3, denoted by peak height and area. The high non-toxic polar antioxidant activity observed in fraction 5 may be contributed by the three compounds represented by elution peaks having retention times of $0.8,0.9$ dan 1.0 minutes. Peaks with retention times 0.8 and 0.9 minutes were also present in fractions 3 and 7 but with much-diminished concentration compared to fraction 5 .

Without comparison to pure known compounds, compounds present in each fraction cannot be identified yet based solely on the HPLC chromatogram profiles. At this stage, it can only be concluded that each fraction's composition is markedly different and still contain several compounds. From the chromatogram profiles in fraction 5, at least three compounds may contribute to the 
high non-toxic polar antioxidant present. The literature search suggests several candidate compounds that may be present in fraction 5. Zarena and Sankar [28] reported several compounds as polar phenolic acids present as free phenolic acids with relatively high concentrations (0.1 to $2 \mathrm{mg}$ per $\mathrm{g}$ sample) in mangosteen pericarp are gallic acid, protocatechuic acid, caffeic acid, syringic acid, ferulic acid, and epicatechin. Abdallah et al. [11] isolated epicatechin and $2,3^{\prime}, 4,5^{\prime}, 6$-pentahydroxy benzophenone as polar phenolic compounds from mangosteen pericarp having protective effects against vascular damage by reactive oxygen species.

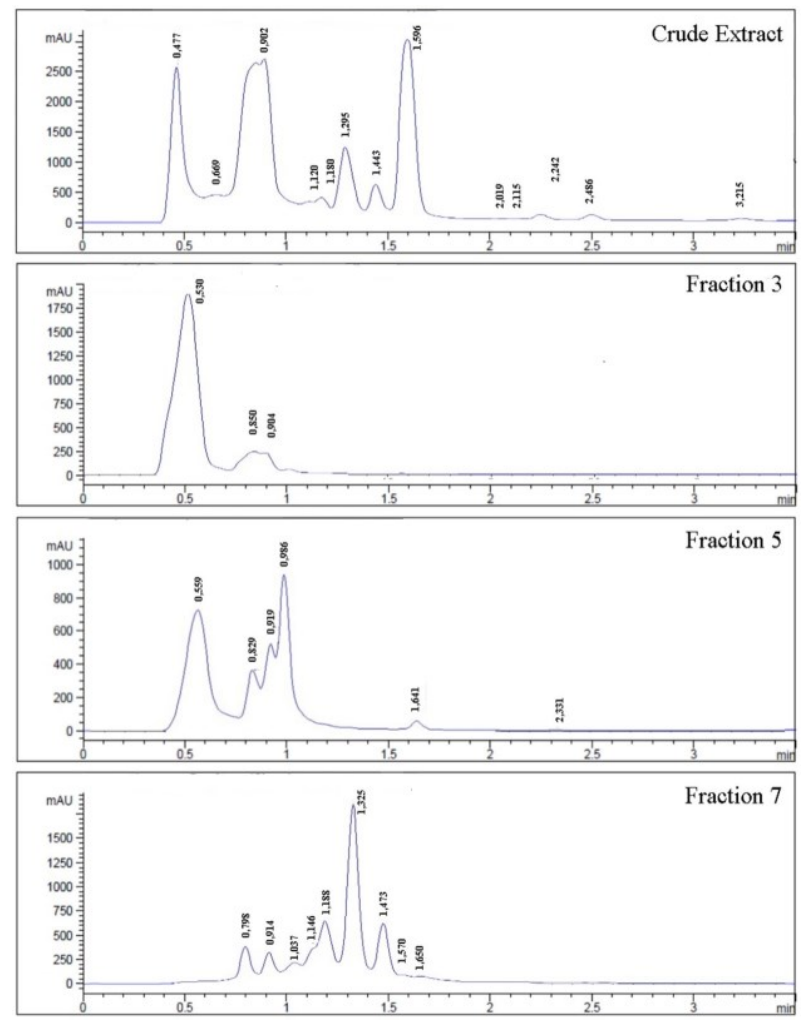

Figure 1. Reverse-phase HPLC chromatogram profiles of crude mangosteen pericarp extracts and RP-LC fractions with high antioxidant activity detected at $240 \mathrm{~nm}$. Numbers above peaks denote retention time in minutes of each peak identified.

Polar polyphenols from mangosteen fruit pericarp have the potential to be used as a medication or food supplement to prevent and treat neurodegenerative diseases [29] or to prevent cardiovascular diseases [11]. This is due to the high antioxidants of polar phenolics in mangosteen having the ability to reduce Reactive Oxygen Species activity, stimulate Nitric Oxide (NO) generation, and inhibit acetylcholine esterases. However, a mangosteen extract containing polar antioxidants for prolonging consumption as a nutritional supplement or as preventive medication should not contain any cell toxic elements. As shown in this study, crude polar $50 \%$ ethanol extracts of mangosteen fruit pericarp contain toxic compounds. The toxic compounds in the crude polar extracts could be easily separated from the beneficial compounds using a simple RP-LC method. The RP-LC method affords to upscale to industrial levels in a continuous process with minimal organic solvent usage. Suthammarak et al. [30] prepared a non-toxic polar fraction of mangosteen pericarp using a different method by partitioning the toxic compounds into ethyl acetate. The partitioning method employed by Suthammarak et al. [30] uses a large amount of organic solvent. In the RP-LC method, the use of organic solvent can be kept to a minimum, so less organic solvent waste. The RP-LC stationary phase can be reused by regeneration, with washing using less solvent than the partition method, so that the stationary phase's cost can be reduced.

\section{Conclusion}

RP-LC of crude polar $50 \%$ ethanol extracts of mangosteen fruit pericarp is an excellent method to separate non-toxic polar phenolics from toxic compounds. A non-toxic fraction with high antioxidant activity and high TPC could be obtained using an RP-LC procedure. Toxic compounds in crude polar 50\% ethanol extracts of mangosteen fruit pericarp have lower polarity than the non-toxic compounds.

\section{Acknowledgment}

This research was funded by research grant "Hibah Penelitian Universitas Riau Skim Penelitian Guru Besar", under contract no 626/UN.19.5.1.3/PP/2018.

\section{References}

[1] Guoqing Chen, Yong Li, Wei Wang, Liping Deng, Bioactivity and pharmacological properties of $\alpha-$ mangostin from the mangosteen fruit: a review, Expert Opinion on Therapeutic Patents, 28, 5, (2018), 415-427

https://doi.org/10.1080/13543776.2018.1455829

[2] Kuo-jun Zhang, Qin-lan Gu, Kan Yang, Xian-jun Ming, Jin-xin Wang, Anticarcinogenic Effects of $\alpha-$ Mangostin: A Review, Planta Med, 83, 03/04, (2017), 188-202 https://doi.org/10.1055/s-0042-119651

[3] Wan Mohd Aizat, Faridda Hannim Ahmad-Hashim, Sharifah Nabihah Syed Jaafar, Valorization of mangosteen, "The Queen of Fruits," and new advances in postharvest and in food and engineering applications: A review, Journal of Advanced Research, 20, (2019), 61-70 https://doi.org/10.1016/j.jare.2019.05.005

[4] Gamal A. Mohamed, Ahmed M. Al-Abd, Ali M. Elhalawany, Hossam M. Abdallah, Sabrin R. M. Ibrahim, New xanthones and cytotoxic constituents from Garcinia mangostana fruit hulls against human hepatocellular, breast, and colorectal cancer cell lines, Journal of Ethnopharmacology, 198, (2017), 302-312 https://doi.org/10.1016/j.jep.2017.01.030

[5] Berenice Ovalle-Magallanes, Dianelena EugenioPérez, José Pedraza-Chaverri, Medicinal properties of mangosteen (Garcinia mangostana L.): A comprehensive update, Food and Chemical Toxicology, 109, (2017), 102-122 https://doi.org/10.1016/j.fct.2017.08.021

[6] Joko Suryadi, Gunawan Gunawan, Abdul Haris, Pembuatan dan Penentuan Nilai Efisiensi Sel Surya Berpewarna Tersensitisasi dengan Senyawa Antosianin dari Buah Manggis (Garcinia mangostana L.) sebagai Pewarna Pensensitisasi, Jurnal Kimia Sains dan Aplikasi, 13, 3, (2010), 88-94 https://doi.org/10.14710/jksa.13.3.88-94 
[7] Wan Mohd. Aizat, Ili Nadhirah Jamil, Faridda Hannim Ahmad-Hashim, Normah Mohd. Noor, Recent updates on metabolite composition and medicinal benefits of mangosteen plant, PeerJ, 7, (2019), e6324 https://doi.org/10.7717/peerj.6324

[8] Dini Kurnia Wisatya, Purbowatiningrum Ria Sarjono, Nies Suci Mulyani, Pengaruh Pemanasan pada Proses Pembuatan Ekstrak Kulit Buah Manggis (Garcinia mangostana Linn) terhadap Aktivitas Antimikroba, Jurnal Kimia Sains dan Aplikasi, 13, 2, (2010), 46-50

https://doi.org/10.14710/jksa.13.2.46-50

[9] Primchanien Moongkarndi, Nattapon Jaisupa, Jutima Samer, Nuttavut Kosem, Julaporn Konlata, Ekkarat Rodpai, Narongchai Pongpan, Comparison of the biological activity of two different isolates from mangosteen, Journal of Pharmacy and Pharmacology, 66, 8, (2014), 1171-1179 https://doi.org/10.1111/jphp.12239

[10] Werayut Pothitirat, Mullika Traidej Chomnawang, Roongtawan Supabphol, Wandee Gritsanapan, Free radical scavenging and anti-acne activities of mangosteen fruit rind extracts prepared by different extraction methods,

Biology, 48, 2, (2010), 182-186

https://doi.org/10.3109/13880200903062671

[11] Hossam M. Abdallah, Hany M. El-Bassossy, Gamal A. Mohamed, Ali M. El-halawany, Khalid Z. Alshali, Zainy M. Banjar, Phenolics from Garcinia mangostana alleviate exaggerated vasoconstriction in metabolic syndrome through direct vasodilatation and nitric oxide generation, $B M C$ Complementary and Alternative Medicine, 16, 1, (2016), 359

https://doi.org/10.1186/s12906-016-1340-5

[12] Titin Andri Wihastuti, Fitria Nugraha Aini, Cholid Tri Tjahjono, Teuku Heriansyah, Dietary Ethanolic Extract of Mangosteen pericarp Reduces VCAM-1, Perivascular Adipose Tissue and Aortic Intimal Medial Thickness in Hypercholesterolemic Rat Model, Open access Macedonian journal of medical sciences, $7,19,(2019), 3158$ https://dx.doi.org/10.3889/oamjms.2019.717

[13] Weerayuth Suttirak, Supranee Manurakchinakorn, In vitro antioxidant properties of mangosteen peel extract, Journal of Food Science and Technology, 51, 12, (2014), 3546-3558 https://doi.org/10.1007/s13197-012-0887-5

[14] Titania Tjandrawati Nugroho, Hilwan Yuda Teruna, Yuana Nurulita, Penggunaan selulase Trichoderma asperellum untuk peningkatan ekstraksi senyawa polar antioksidan dari kulit buah Garcinia mangostana $L$ sebagai neuroprotektan, Lembaga Penelitian Universitas Riau, Pekanbaru, 2016

[15] Fitri Rahmayanti, Miranti Miranti, Hilwan Yuda Teruna, Titania Tjandrawati Nugroho, Removal of Cytotoxicity From A Mangosteen Polar Antioxidant Extract By Gel Filtration Chromatography, International Journal of Science and Applied Technology, 3, 2, (2018), 1-6

[16] Bénédicte Lorrain, Isabelle Ky, Laurent Pechamat, Pierre-Louis Teissedre, Evolution of Analysis of Polyhenols from Grapes, Wines, and Extracts, Molecules, 18, 1, (2013), 1076-1100 https://doi.org/10.3390/molecules18011076
[17] Miranti, Uji Aktivitas Antioksidan serta Kandungan Fenolik dan Tanin Ekstrak Etanol 50\% Kulit Buah Manggis dengan Bantuan Selulase Trichoderma asperellum LBKURCC1, master thesis, Universitas Riau, Pekanbaru, 2015

[18] Qing Zhang, Junzeng Zhang, Jingkai Shen, Angelica Silva, Dorothy A. Dennis, Colin J. Barrow, A Simple 96-Well Microplate Method for Estimation of Total Polyphenol Content in Seaweeds, Journal of Applied Phycology, 18, 3, (2006), 445-450 https://doi.org/10.1007/s10811-006-9048-4

[19] Andressa Blainski, Gisely C. Lopes, João C. De Mello, Application and Analysis of the Folin Ciocalteu Method for the Determination of the Total Phenolic Content from Limonium Brasiliense L, Molecules, $18,6,(2013), 6852-6865$ https://doi.org/10.3390/molecules18066852

[20] Ludmila Machu, Ladislava Misurcova, Jarmila Vavra Ambrozova, Jana Orsavova, Jiri Mlcek, Jiri Sochor, Tunde Jurikova, Phenolic Content and Antioxidant Capacity in Algal Food Products, Molecules, 20, 1, (2015), 1118-1133 https://doi.org/10.3390/molecules20011118

[21] Mentor R. Hamidi, Blagica Jovanova, Tatjana Kadifkova Panovska, Toxicological evaluation of the plant products using Brine Shrimp (Artemia salina L.) model, Makedonsko Farmacevtski Bilten, 60, 1, (2014), 9-18

[22] David John Finney, Probit Analysis, Cambridge University Press, 2009

[23] David B. Duncan, Multiple range and multiple F tests, Biometrics, 11, 1, (1955), 1-42 https://doi.org/10.2307/3001478

[24] H. Leon Harter, Critical values for Duncan's new multiple range test, Biometrics, 16, 4, (1960), 671685 https://doi.org/10.2307/2527770

[25] Wahyuningsih, Fraksinasi kromatografi kolom fasa terbalik ekstrak polar senyawa antioksidan kulit manggis (Garcinia mangostana Linn), master thesis, Universitas Riau, Pekanbaru, 2020

[26] Souwalak Phongpaichit, Jaru Nikom, Nattawut Rungjindamai, Jariya Sakayaroj, Nongporn Hutadilok-Towatana, Vatcharin Rukachaisirikul, Kanyawim Kirtikara, Biological activities of extracts from endophytic fungi isolated from Garcinia plants, FEMS Immunology \& Medical Microbiology, 51, 3, (2007), 517-525 https://doi.org/10.1111/j.1574-695X.2007.00331.X

[27] Hashini I. Abeysuriya, Vajira P. Bulugahapitiya, Jayatissa Loku Pulukkuttige, Total Vitamin C, Ascorbic Acid, Dehydroascorbic Acid, Antioxidant Properties, and Iron Content of Underutilized and Commonly Consumed Fruits in Sri Lanka, International Journal of Food Science, 2020, (2020), 4783029 https://doi.org/10.1155/2020/4783029

[28] A. S. Zarena, K. Udaya Sankar, Phenolic Acids, Flavonoid Profile and Antioxidant Activity in Mangosteen (Garcinia mangostana L.) Pericarp, Journal of Food Biochemistry, 36, 5, (2012), 627-633 https://doi.org/10.1111/j.1745-4514.2011.00575.x

[29] Jintana Sattayasai, Pongsatorn Chaonapan, Tarinee Arkaravichie, Rungtip Soi-ampornkul, Sarawut Junnu, Patcharakajee Charoensilp, Jutima Samer, Jiraporn Jantaravinid, Patarabutr Masaratana, 
Bhoom Suktitipat, Juthatip Manissorn, Visith Thongboonkerd, Neelobol Neungton, Primchanien Moongkarndi, Protective Effects of Mangosteen Extract on $\mathrm{H}_{2} \mathrm{O} 2$-Induced Cytotoxicity in SK-N-SH Cells and Scopolamine-Induced Memory Impairment in Mice, PLOS ONE, 8, 12, (2013), e85053 https://doi.org/10.1371/journal.pone.0085053

[30] Wichit Suthammarak, Pornpayom Numpraphrut, Ratiya Charoensakdi, Neelobol Neungton, Vachara Tunrungruangtavee, Nattapon Jaisupa, Suwit Charoensak, Primchanien Moongkarndi, Weerasak Muangpaisan, Antioxidant-Enhancing Property of the Polar Fraction of Mangosteen Pericarp Extract and Evaluation of Its Safety in Humans, Oxidative Medicine and Cellular Longevity, 2016, (2016), 1293036 https://doi.org/10.1155/2016/1293036 